\title{
Evaluation of disease activity in rheumatic patients by leucocyte adhesiveness/aggregation
}

\author{
SHLOMO BERLINER, ${ }^{1}$ MOSHE FRIED, ${ }^{1}$ DAN CASPI, ${ }^{2}$ \\ ABRAHAM WEINBERGER, ${ }^{1}$ MICHAEL YARON ${ }^{2}$ JACK PINKHAS, ${ }^{1}$ AND \\ MOSHE ARONSON ${ }^{3}$
}

From the ${ }^{1}$ Department of Internal Medicine ' $D$ ' and the Rheumatologic Unit at the Belinson Medical Center, ${ }^{\omega}$ Petah Tiqva; the ${ }^{2}$ Department of Rhematology at the Tel Aviv Medical Center, Tel Aviv; and the ${ }^{3}$ Department $t_{\frac{0}{0}}$ of Cell Biology at the Sackler Faculty of Medicine; Tel Aviv University, Tel Aviv, Israel

SUMMARY Previous work has shown that leucocyte adhesiveness/aggregation (LAA), as

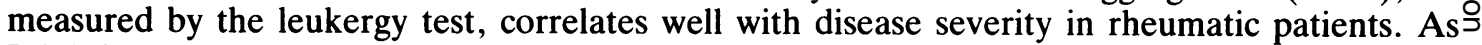
LAA is probably a manifestation of the acute phase reaction various components of the acute $\vec{c}$ phase reaction were measured in order to identify the best marker of disease activity. In addition to LAA, the following variables were measured in 79 patients with various rheumatic diseases ${ }_{-}^{\Phi}$ and in 10 controls: white blood cell and platelet counts, erythrocyte sedimentation rate,,$\infty$ haptoglobin, fibrinogen, $C$ reactive protein, albumin, globulin, caeruloplasmin, $\alpha_{1}, \alpha_{2}, \beta$, and $\gamma^{\circ}$ globulin, and haemoglobin concentrations. Patients were graded according to the state of theiro disease as mild, moderate, or severe. The extent of leucocyte adhesiveness/aggregation in peripheral blood proved to be the best laboratory variable for the grading of disease activity. Correct grading was obtained in $63 \%$ of the patients by means of the LAA, compared with $48 \% \frac{\circ}{\varnothing}$ with $\mathrm{C}$ reactive protein, $41 \%$ with caeruloplasmin, $40 \%$ with haptoglobin, and $32 \%$ with $\stackrel{\varrho}{\Rightarrow}$ haemoglobin. It is suggested that LAA of the peripheral blood during inflammation may be used as a reliable marker of disease severity.

The present investigation is an extension of a previous attempt to develop a laboratory tool for the assessment of disease activity in rheumatic patients. ${ }^{1}$ Total white blood cell count and erythrocyte sedimentation rate (ESR) were compared by the leukergy test, which determines the extent of leucocyte adhesiveness and aggregation (LAA). It was found that LAA measurements yielded the most reliable results and pointed to the usefulness of the test in clinical work.

As LAA is only one of many variables in the acute phase reaction which may change during inflammation (for a concise description of the latter see reference 2) it was decided to examine a large number of these variables and correlate them with the state of disease activity in various types of rheumatic disorders. Although LAA again gave the best results, some other markers, such as $\mathrm{C}$ reactive

Accepted for publication 12 November 1987.

Correspondence to Professor Moshe Aronson, Department of Cell Biology and Histology, Sackler Faculty of Medicine, Tel Aviv University, 69978 Tel Aviv, Israel. protein, caeruloplasmin, etc, also showed significant correlation with the state of disease activity.

\section{Patients and methods}

PAT I ENTS

Seventy nine patients with various rheumatic dis- $\rightarrow$ eases, all being followed up by the unit of rheumatology at the Beilinson Medical Center and at the N Department of Rheumatology of the Tel Avivo Medical Center, gave their written consent to 0 participate. Blood samples from the antecubital vein $\omega$ were drawn during the morning when the patients? were evaluated by senior physicians who were noto aware of the results of laboratory tests and who classified them into three categories according to the $?$ following criteria: group A-Mild disease; patients with various rheumatic diseases presenting minimal $\stackrel{0}{\mathbb{\Phi}}$ complaints and physical findings. These patients maintained normal daily activities and took a small $\stackrel{\varnothing}{\varrho}$ quantity of anti-inflammatory drugs. Group B-O Moderate disease; presenting clear cut symptoms 0 and signs of active disease. These patients suffered 
moderate impairment of their daily activities and were given full doses of conventional antiinflammatory drugs. Group C-Severe disease; patients in hospital for intensive treatment owing to florid disease, with significant complaints, physical findings, and inability to continue normal daily activities. At times, significant involvement of an internal organ, such as lupus nephritis, was sufficient to classify the patient in this category.

\section{CONTROLS}

Ten healthy paramedical personnel volunteered to serve as controls.

\section{METHODS}

The LAA was determined by a previously described method. ${ }^{1 \text { 3-6 }}$ In brief, a citrated sample of blood (1:4 dilution of a $3.8 \%$ sodium citrate solution, i.e., one volume of citrate and three volumes of blood) was drawn into a plastic syringe. Several large drops of blood were placed on a slide, which was slanted for a few seconds to allow the blood to run down by gravity. The slides were dried in an incubator or at room temperature, then cooled to $-10^{\circ} \mathrm{C}$ for 10 minutes, and, finally, thawed by blowing several times on the slide. This haemolysed the erythrocytes without affecting the leucocytes. After fixation with methanol the smears were stained in haematoxylin for five minutes. The percentage of aggregated leucocytes on the slide was determined by counting 300 cells. Cells were considered aggregated when three or more nuclei were located less than one cell diameter apart. Two slides were prepared from each patient, the final percentage of aggregated leucocytes being a simple mean of the two. This test has intra-assay and interassay coefficients of variation of 0.2 and 0.3 respectively. Estimates of white blood cells, platelets, and haemoglobin were obtained by a Coulter $\mathrm{S}+$ counter.

The erythrocyte sedimentation rate was determined by the method of Westergren. ${ }^{7}$

The concentration of haptoglobin in the serum was determined by radial immunodiffusion (according to the method of Mancini et $a l^{8}$ ) using a commercial antibody to human haptoglobin.

The plasma concentration of fibrinogen was determined according to the method of Clauss. ${ }^{9}$

The concentration of $\mathrm{C}$ reactive protein (CRP) was determined by electroimmunoassay ${ }^{10}$ using specific antiserum and a standard reference serum.

The serum concentration of albumin and globulin was determined in the sequential multiple analyser SMA 12.

The concentration of caeruloplasmin in the serum was determined by an enzymatic assay as described elsewhere. ${ }^{11}$
The various globulins were determined by electrophoresis using a Beckman model R-101 electrophoresis cell.

\section{STATISTICAL ANALYSIS}

Statistical analysis was performed using the BMDP (Biomedical computer programs, P series, 1979, University of California). One way analysis of variance was done for each laboratory variable to verify whether at least one significant difference existed between test groups and the control. A multiple regression analysis was performed ${ }^{12}$ using the group $(0=$ control, $1=$ mild, $2=$ moderate, and $3=$ severe) as the outcome variable to ascertain the variable that best discriminated between groups of disease activity. The percentage of correct classification into the appropriate group of severity was calculated by means of discriminant analysis ${ }^{13}$ for the variables that showed the best ability to classify the patients.

\section{Results}

We examined 79 patients and 10 controls. Table 1 shows the classification of the patients into groups of disease activity and the age and sex of patients and controls. Of the 27 patients in the group with mild disease, 20 had rhematoid arthritis (RA), three had psoriatic arthritis, two had monarthritis of undefined aetiology, one had gouty arthritis, and the remaining one mixed connective tissue disease. In the group with moderate disease there were 28 patients, of whom 21 had RA, two had systemic lupus erythematosus, two had psoriatic arthritis, one had monarthritis of undefined aetiology, and one juvenile arthritis. In the group with severe disease 23 patients had RA and one psoriatic arthritis.

Table 2 shows the results of the laboratory variables examined and the level of significance for the analysis of variance. It can be seen that 10 variables attained significance $(p<0.05)$ in this analysis-namely, LAA, total white blood cell count, platelet count, erythrocyte sedimentation

Table 1 Classification of patients into disease categories, age, and sex

\begin{tabular}{|c|c|c|c|c|}
\hline & \multirow[t]{2}{*}{ Controls } & \multicolumn{3}{|c|}{ Disease status } \\
\hline & & Mild & Moderate & Severe \\
\hline Age (years) & $70(5)^{*}$ & 51.9 (13) & 57 (16) & $66.5(12)$ \\
\hline Range & $63-80$ & $25-78$ & $17-75$ & $38-79$ \\
\hline $\begin{array}{l}\text { subjects } \\
\text { Men/women }\end{array}$ & $\begin{array}{l}10 \\
5 / 5\end{array}$ & $\begin{array}{l}27 \\
6 / 21\end{array}$ & $\begin{array}{l}28 \\
13 / 15\end{array}$ & $\begin{array}{l}24 \\
4 / 20\end{array}$ \\
\hline
\end{tabular}

*Values are mean (SD). 
Table 2 Distribution of laboratory variables among patient groups*

\begin{tabular}{|c|c|c|c|c|c|c|}
\hline \multirow[t]{2}{*}{ Variable } & \multirow{2}{*}{$\begin{array}{l}\text { Control } \\
(n=10)\end{array}$} & \multicolumn{3}{|c|}{ Disease status } & \multirow{2}{*}{$\begin{array}{l}\text { ANOVA } \\
\text { ( } p \text { value })\end{array}$} & $\div \overline{\mathscr{S}}$ \\
\hline & & $\begin{array}{l}\text { Mild } \\
(n=27)\end{array}$ & $\begin{array}{l}\text { Moderate } \\
(n=28)\end{array}$ & $\begin{array}{l}\text { Severe } \\
(n=24)\end{array}$ & & $\frac{\bar{c}}{\bar{\sigma}}$ \\
\hline \multirow[t]{2}{*}{$\mathrm{LAA} \div(\%)$} & $3(1.4)$ & $5 \cdot 3(2 \cdot 2)$ & $13 \cdot 9(6 \cdot 8)$ & $21 \cdot 8(10 \cdot 6)$ & \multirow[t]{2}{*}{$<0 \cdot 0001$} & $\stackrel{\mathbb{2}}{\varrho}$ \\
\hline & $1-6$ & $1-9$ & $7-43$ & $11-52$ & & $\overline{0}$ \\
\hline \multirow[t]{2}{*}{ WBC $\dagger\left(\times 10^{4} / \mathrm{l}\right)$} & $6.74(1.63)$ & $6.49(1.63)$ & $7.82(1.39)$ & $7.99(2 \cdot 84)$ & \multirow[t]{2}{*}{$<0.05$} & \\
\hline & $4 \cdot 7-9 \cdot 2$ & $3 \cdot 6-11 \cdot 0$ & $5 \cdot 7-11 \cdot 0$ & $3 \cdot 2-14 \cdot 0$ & & $\overrightarrow{0}$ \\
\hline \multirow[t]{2}{*}{ Platelets $\left(\times 10^{\varphi} / 1\right)$} & $202(34)$ & $220(83)$ & $251(84)$ & $287(96)$ & \multirow[t]{2}{*}{$<0.05$} & $=$ \\
\hline & $125-240$ & $105-384$ & 9()$-500$ & $141-480$ & & $\vec{\omega}$ \\
\hline \multirow[t]{2}{*}{$\operatorname{ESR~} 1 \dagger(\mathrm{mm} / 1 \mathrm{st} \mathrm{h})$} & $20(14)$ & $18(16)$ & $29(17)$ & $62(30)$ & \multirow[t]{2}{*}{$<0 \cdot 0001$} & న \\
\hline & $8-45$ & $2-64$ & $4-80$ & $5-131$ & & $\stackrel{2}{2}$ \\
\hline \multirow[t]{2}{*}{ ESR $2(\mathrm{~mm} / 2 \mathrm{nd} \mathrm{h})$} & $34(15)$ & $37(25)$ & $53(24)$ & $90(33)$ & \multirow[t]{2}{*}{$<0 \cdot 0001$} & 으 \\
\hline & $15-50$ & $4-95$ & $8-95$ & $10-137$ & & 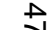 \\
\hline \multirow[t]{2}{*}{ Haptoglobin $(\mathrm{g} / \mathrm{l})$} & $1.9(0.57)$ & $1.57(0.67)$ & $2.27(0.77)$ & $2 \cdot 5(0 \cdot 83)$ & \multirow{2}{*}{$=0 \cdot 0001$} & هं \\
\hline & $1 \cdot 1-2 \cdot 8$ & $0 \cdot 5-3 \cdot 4$ & $0 \cdot 95-3 \cdot 6$ & $1 \cdot 1-4 \cdot 0$ & & \\
\hline \multirow[t]{2}{*}{ Fibrinogen $(\mathrm{g} / \mathrm{l})$} & $3.53(0 \cdot 63)$ & $3.32(1.05)$ & $3.75(1.17)$ & $4.05(1.29)$ & \multirow[t]{2}{*}{$=0 \cdot 1344$} & $\dot{0}$ \\
\hline & $2 \cdot 81-4 \cdot 6$ & $1 \cdot 8-6 \cdot 6$ & $1.9-6 \cdot 8$ & $1 \cdot 8-7 \cdot 1$ & & \\
\hline \multirow[t]{2}{*}{$\mathrm{CRP}+(\mathrm{mg} / \mathrm{l})$} & $9(10)$ & $6 \cdot 6(11)$ & $17(18)$ & $36(29)$ & \multirow[t]{2}{*}{$<0 \cdot 0001$} & 익 \\
\hline & $0-26$ & $0-53$ & $0-81$ & $0-109$ & & $\rightarrow$ \\
\hline \multirow[t]{2}{*}{ Albumin (g/l) } & $41(4)$ & $40(3)$ & $37(4)$ & $38(3)$ & \multirow[t]{2}{*}{$<0.05$} & $\subseteq$ \\
\hline & $37-51$ & $32-47$ & $28-45$ & $30-44$ & & \\
\hline \multirow[t]{2}{*}{ Globulin (g/l) } & $27(3)$ & $29(4)$ & $27(7)$ & $28(6)$ & \multirow[t]{2}{*}{$=0.6267$} & t \\
\hline & $22-31$ & $16-36$ & $14-38$ & $12-38$ & & $\overrightarrow{0}$ \\
\hline \multirow[t]{2}{*}{ Caeruloplasmin (units) } & $577(85)$ & $653(141)$ & $697(167)$ & $872(161)$ & \multirow[t]{2}{*}{$<0 \cdot 0001$} & $\infty$ \\
\hline & $490-760$ & $254-940$ & $380-1032$ & $663-1330$ & & \\
\hline \multirow[t]{2}{*}{$\alpha_{1}$ Globulin (\%) } & $3 \cdot 3(1 \cdot 3)$ & $3 \cdot 5(1 \cdot 5)$ & $4 \cdot 4(1 \cdot 7)$ & $4 \cdot 3(1 \cdot 3)$ & \multirow[t]{2}{*}{$=0 \cdot 05$} & ? \\
\hline & $2-6$ & $2-7$ & $3-8$ & $3-8$ & & $\stackrel{0}{\Sigma}$ \\
\hline \multirow[t]{2}{*}{$\alpha_{2}$ Globulin ( $\%$ ) } & $10 \cdot 5(3 \cdot 2)$ & $11 \cdot 5(3 \cdot 7)$ & $12(3 \cdot 7)$ & $13 \cdot 8(2 \cdot 3)$ & $=0 \cdot 1223$ & $\grave{\bar{\Omega}}$ \\
\hline & $7-16$ & $7 \cdot 5-17$ & $7 \cdot 5-22$ & $10-20$ & & ర్ \\
\hline$\beta$ Globulin $(\%)$ & $12(3 \cdot 8)$ & $12 \cdot 7(4)$ & $12 \cdot 2(3)$ & $14 \cdot 2(2 \cdot 7)$ & $=0 \cdot 1464$ & 응 \\
\hline & $7-17$ & $7 \cdot 5-18$ & $9-16$ & $9-22$ & & 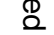 \\
\hline$\gamma$ Globulin $(\%)$ & $16(5 \cdot 2)$ & $16 \cdot 4(5 \cdot 5)$ & $18 \cdot 7(6 \cdot 4)$ & $19 \cdot 8(3 \cdot 8)$ & $=0 \cdot 1395$ & $\bar{\Rightarrow}$ \\
\hline & $10 \cdot 4-24$ & $10 \cdot 8-26$ & $10 \cdot 8-31$ & $12-26$ & & \\
\hline Haemoglobin (g/l) & $144(9)$ & $134(14)$ & $130(15)$ & $124(13)$ & $<0 \cdot(005$ & 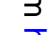 \\
\hline & $132-161$ & $100-170$ & $100-160$ & $96-153$ & & 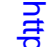 \\
\hline
\end{tabular}

rates at the first (ESR 1) and second (ESR 2) hour, haptoglobin, $\mathrm{C}$ reactive protein, albumin, caeruloplasmin, and haemoglobin. Table 3 shows the correlation (Pearson) between the laboratory vari-

Table 3 Correlation (Pearson) between laboratory variables and disease severity

\begin{tabular}{lc}
\hline Variable & Correlation coefficient \\
\hline LAA & $0 \cdot 71$ \\
WBC & $0 \cdot 28$ \\
Platelets & $0 \cdot 34$ \\
ESR (1st hour) & $0 \cdot 486$ \\
ESR (2nd hour) & $0 \cdot 486$ \\
Haptoglobin & $0 \cdot 39$ \\
Fibrinogen & $0 \cdot 22$ \\
CRP & $0 \cdot 43$ \\
Globulin & $-0 \cdot 15$ \\
Caeruloplasmin & $0 \cdot 53$ \\
Haemoglobin & $-0 \cdot 4$ \\
Albumin & $-0 \cdot 23$ \\
\hline
\end{tabular}

ables and disease severity. It can be seen that LAA caeruloplasmin, and ESR 1 gave the best results? (As there was no difference between ESR 1 and $\mathcal{F}$ we relate only to the former.) Stepwise regression analysis showed the following $\mathrm{R}^{2}$ values: LAA alone. $0 \cdot 50$, LAA with ESR $0 \cdot 58, \mathrm{LAA}+\mathrm{ESR}+$ caerulof plasmin $0 \cdot 60$.

Table 4 shows the regression coefficients. The degree of severity would therefore be $0 \cdot 063+0 \cdot 005 \%$ $\times$ LAA values $+0 \cdot 0074 \times$ ESR $1+0 \cdot 001 \times$ caeruloplas $\min$.

Table 4 Stepwise regression analysis

\begin{tabular}{|c|c|c|}
\hline Variable & $\begin{array}{l}\text { Regression } \\
\text { coefficient ( } \beta \text { ) }\end{array}$ & $\begin{array}{l}\text { Significance } \\
(p \text { value })\end{array}$ \\
\hline LAA & $0 \cdot 0565$ & 0.001 \\
\hline ESR 1 & 0.00737 & 0.011 \\
\hline Caeruloplasmin & 0.00101 & 0.29 \\
\hline Constant & 0.06265 & \\
\hline
\end{tabular}


By means of discriminant analysis (Tables 5-7) we calculated the correct classification by the most promising variables: LAA alone and LAA + CRP. It can be seen, for example, that by means of LAA and CRP, 17 of the 27 patients in the mild disease category were classified in that particular group, nine were classified as controls, and one as having moderate disease. Of 28 patients in the moderate disease group, four were classified as mild, 19 as moderate, five as severe, and none as controls. The total percentage of correct classification by means of LAA and CRP was $69 \%$, that by LAA alone was $63 \%$, and that by CRP alone was $48 \%$. Table 8 gives the results of classification by LAA+ESR 1 , and

Table 5 Classification of patients into the correct category of disease by means of $L A A$ plus $C R P$

\begin{tabular}{|c|c|c|c|c|c|}
\hline \multirow[t]{2}{*}{ Category } & \multirow{2}{*}{$\begin{array}{l}\text { Percentage } \\
\text { of correct } \\
\text { classification }\end{array}$} & \multicolumn{4}{|c|}{$\begin{array}{l}\text { Number of patients classified into } \\
\text { the following categories: }\end{array}$} \\
\hline & & Control & Mild & Moderate & Severe \\
\hline Control & 90 & 9 & 1 & 0 & 0 \\
\hline Mild & 63 & 9 & 17 & 1 & 0 \\
\hline Moderate & 68 & 0 & 4 & 19 & 5 \\
\hline Severe & 63 & 0 & 0 & 9 & 15 \\
\hline
\end{tabular}

Total percentage of correct classification $67 \%$.

Table 6 Classification of patients into the correct category of disease by means of LAA alone

\begin{tabular}{llrrrr}
\hline Category & $\begin{array}{l}\text { Percentage } \\
\text { of correct } \\
\text { classification }\end{array}$ & $\begin{array}{l}\text { Number of patients classified into } \\
\text { the following categories: }\end{array}$ \\
\cline { 3 - 6 } & & Control & Mild & Moderate & Severe \\
\hline Control & 90 & 9 & 1 & 0 & 0 \\
Mild & 59 & 11 & 16 & 0 & 0 \\
Moderate & 61 & 0 & 6 & 17 & 5 \\
Severe & 58 & 0 & 0 & 10 & 14 \\
\hline
\end{tabular}

Total percentage of correct classification $63 \%$.

Table 7 Classification of patients into the correct category of disease by means of CRP alone

\begin{tabular}{llllll}
\hline Category & $\begin{array}{l}\text { Percentage } \\
\text { of correct } \\
\text { classification }\end{array}$ & $\begin{array}{l}\text { Number of patients classified into } \\
\text { the following categories: }\end{array}$ \\
\cline { 3 - 6 } & & Control & Mild & Moderate & Severe \\
\hline Control & 30 & 3 & 5 & 2 & 0 \\
Mild & 70 & 3 & 19 & 4 & 1 \\
Moderate & 29 & 4 & 9 & 8 & 7 \\
Severe & 54 & 4 & 4 & 3 & 13 \\
\hline
\end{tabular}

Total percentage of correct classification $48 \%$.
Table 8 Classification of patients into the correct category of disease by means of LAA plus ESR (1st hour)

\begin{tabular}{llllll}
\hline Category & $\begin{array}{l}\text { Percentage } \\
\text { of correct } \\
\text { classification }\end{array}$ & $\begin{array}{l}\text { Number of patients classified into } \\
\text { the following categories: }\end{array}$ \\
\cline { 3 - 6 } & & Control & Mild & Moderate & Severe \\
\hline Control & 50 & 5 & 5 & 0 & 0 \\
Mild & 70 & 7 & 19 & 1 & 0 \\
Moderate & 64 & 2 & 6 & 18 & 2 \\
Severe & 79 & 0 & 0 & 5 & 19 \\
\hline
\end{tabular}

Total percentage of correct classification $69 \%$.

although the overall result is as good as that of LAA+CRP, there is a considerable worsening in the control group in comparison with LAA alone, as ESR 1 did not distinguish well between controls and patients with mild disease. For purposes of comparison we also calculated the percentage of correct classification by means of the other variables which showed significance in the discriminant analysis. We obtained $41 \%$ for caeruloplasmin, $40 \%$ for haptoglobin, and $32 \%$ for haemoglobin. Therefore, LAA seems to be the best laboratory variable for classifying patients into categories of disease severity.

\section{Discussion}

The state of leucocyte adhesiveness/aggregation proved to be a reliable laboratory test for classifying patients into categories of disease activity. It was clearly superior to the variables of the acute phase reaction, including those which are commonly used clinically (e.g., C reactive protein, erythrocyte sedimentation rate, etc).

There is no need to emphasise the importance of estimating the disease severity in rheumatic patients. Although most physicians rely for this purpose on symptoms and signs, it is useful to have laboratory confirmation of the clinical assessment, and such a 'marker' laboratory test could also serve for monitoring the response to treatment as well as for comparing the disease severity in patients from different centres who are given common treatment protocols. To be suitable for this purpose a laboratory test should conform to the following criteria: be performable in every clinic (even if small and far from medical centres), be economical, be rapid, and, of course, be accurate. We believe that the leukergy test fits these criteria in that it can be done in any clinic after brief training, does not require special equipment, costs less than $£ 0.35$ a test, and the results are ready within one hour. As for accuracy, we have already shown previously ${ }^{13}$ and also presently that leukergy is a reliable marker of 
the disease state and in this respect it appears to be better than other commonly used variables of the acute phase reaction. Further, incorrect classifications are no more than one category wrong (mild and severe patients are not confused).

Although the combination of LAA and CRP gives the best results, the simplicity of the ESR test favours its usage. As the ESR does not distinguish well between controls and mild disease activity we suggest using LAA alone to distinguish between non-inflammatory and inflammatory states and the combination of leukergy and ESR to differentiate between the various degrees of the latter.

Apart from its clinical value, the LAA is also of biological interest, for it has been reported previously that various inflammatory conditions are associated with increased leucocyte adhesiveness. ${ }^{14}$ It is believed that some of the factors that mediate leucocyte-leucocyte interactions, may mediate also their interaction with the endothelium. ${ }^{15}$ Increased leucocyte adhesiveness to endothelium is recognised as one of the earliest events in inflammation and probably signals the onset of tissue invasiveness. Increased adherence to the endothelium might be harmful to these cells ${ }^{16}$ and this may play a part in the development of inflammation in various rheumatic diseases. ${ }^{17-21}$

In summary, the state of leucocyte adhesiveness/ aggregation is a simple, convenient, and reliable test for assessing the severity of disease in patients with various rheumatic diseases. In addition to its potential clinical usefulness, this variable also contributes to our understanding of the role of leucocytes in inflammation.

We are indebted to Mrs I Gelernter. MSc. from the statistical advice unit of Tel Aviv University for performing the statistical analysis. We thank Professor M B Pepys. Royal Postgraduate Medical School. London for providing the standard reference serum used in the determination of CRP.

\section{References}

1 Berliner S, Abramovitz M. Kariv N. et al. The leukergy test in rheumatic diseases. New implications for an old test. Arthritis Rheum 1985; 28: 899-903.

2 Pepys M B. Baltz M L. Acute phase proteins with special reference to $\mathrm{C}$-reactive protein and related proteins (pentaxins) and serum amyloid A protein. Adv Immunol 1983; 34: 141-212.

3 Berliner S, Sclarovsky S, Lavie G, Pinkhas J, Aronson M.
Agmon J. The leukergy test in patients with ischemic heart $\stackrel{\text { ? }}{?}$ disease. Am Heart J 1986: 111: 19-22.

4 Kariv N. Medalia O. Aronson M. Leukocyte agglomeration test $\stackrel{\overrightarrow{\mathcal{O}}}{\stackrel{D}{+}}$ to reveal bacterial infections in mice. Lab Anim $S_{c i}$ 1983: 33: 으 361-3.

5 Berliner S, Caspi D. Neuman Y. et al. Aggregation of white $\overline{\bar{\omega}}$ cells and C-reactive protein: a study on the relation between $\vec{\nabla}$ these two indices of the acute phase reaction. J Clin Pathol 1987: 40: 103-6.

6 Berliner S. Fishelson Z. Bruhis S. Kaufman H. Pinkhas J. Aronson $M$. The phenomenon of leukergy. Induction and $\vec{O}$ detection of leukocyte aggregation in whole human blood. $J \vec{\Delta}$ Lab Clin Med 1987: 109: 575-82.

7 International committec for standardization in hematology. Recommendation of measurement of erythrocyte sedimentation rate of human blood. Am J Clin Pathol 1977: 68: 505-7. 으

8 Mancini G. Carbonara A O. Heremans J F. Immunochemical quantitation of antigens by single radial immunodiffusion. Immunochemistry 1965: 2: 235-54

9 Clauss A. Gerinnungsphysiologische Schnellmethode zur Bes- of timmung des Fribrinogens. Acta Haematol Basel 1957: 17:0 $237-46$.

10 Fagen E A. Dyck R F. Maton P N, et al. Serum levels of $\rightarrow$ C-reactive protein in Crohn's disease and ulcerative colitis. Eur $\subseteq$ J Clin Invest 1982: 12: 351-9.

11 Henry J B. Clinical chemistry: principles of techniques. Bern. Stuttgart. Vienna: Huber. 1965: 500-3.

12 Draper N. Smith H. Applied regression analysis. New York: Wiley 1981:307.

13 Morrison D F. The linear discriminant function. In: Morrison D F. ed. Multivariate statistical methods. New York: McGrawHill. 1967: 130-3.

14 Lentnek A L. Schreiber A D. MacGregor R R. The induction of augmented granulocyte adherence by inflammation. Media-응 tion by a plasma factor. J Clin Invest 1976: 57: 11098-103.

15 Harlan J M. Leukocvte-endothelial interactions. Blood 1985: 65: $513-25$.

16 Berliner S. Weinberger M. Ben-Bassat M. et al. Amphotericin $B$ causes aggregation of neutrophils and enhances pulmonary leukostasis. Am Rev Respir Dis 1985: 132: 6(1)2-5.

17 Abramson S B. Given W P. Edelson H S. Weissman G. Neutrophil aggregation induced by sera from patients with active systemic lupus erythematosus. Arthritis Rheum 1983; 26: 630-6.

18 Hashimoto Y. Ziff M. Hurd E R. Increased endothelial cell adherence, aggregation and superoxide generation by neut-O̊ rophils incubated in svstemic lupus erythematosus and Felty's syndrome sera. Arthritis Rheum 1982; 25: 1409-18.

19 Hammerschmidt D E. Bowers T K, Lammi-Keffe C J, Jacob H S. Craddock P R. Granulocyte aggregometry: a sensitive $\frac{D}{O}$ technique for the detection of $\mathrm{C} 5 \mathrm{a}$ and complement activation. Blood 1980; 55: 898-902.

2) Boogaerts M A. Hammerschmidt D E. Roelant C. Verwilghen $\mathrm{R}$ L. Jacob H S. Mechanism of vascular damage in gout and N oxalosis: crystal induced. granulocyte mediated. endothelial injury. Thromb Haemost 1983; 50: 576-80.

$21 \mathrm{Jacob}$ H S. Neutrophil activation as a mechanism of tissue injury. Semin Arthritis Rheum 1983: 13: 144-7. 